\title{
INVESTIGATION OF THE VARIABILITY OF EPSTAL STEEL STRENGTH PARAMETERS
}

\author{
T. CHMIELEWSKI ${ }^{1}$, M . PIOTROWSKA ${ }^{2}$
}

\begin{abstract}
The paper deals with the variability of mechanical properties of EPSTAL steel rods produced in Polish steelworks, i.e. yield stress Re, tensile strength Rm, and elongation Agt. Our study is based on fundamental engineering static room-temperature tensile tests for large series specimens which have been made by manufacturers as the part of a factory quality control. Statistical analysis of these results shows that the stressstrain relationship of steel tensile tests should be described by a one-dimensional stochastic process, and three the most important mechanical parameters, i.e. the yield stress, tensile strength, and elongation by random variables. Based on the statistical elaboration of experimental data, it was found that the yield stress and tensile strength of steel rods produced in the years 2016 - 2017 had the coefficients of variation of less than $3 \%$, and there is a reasonable basis for the manufacturer to increase the characteristic value of EPSTAL steel rods yield stress by a few percentages.
\end{abstract}

Keywords: EPSTAL steel bars, yield stress, tensile strength, elongation, random variables, histograms, main descriptors of a random variable.

\section{INTRODUCTION}

EPSTAL steel is reinforcing steel for reinforced concrete structures. It meets the requirements for the grade of B500SP according to the standards of PN-H-93220 [1] and PN-EN 10080 [2]. It also meets the requirements of class $\mathrm{C}$ according to the Eurocode 2 [3] and the class of A-IIIN according to the old Polish standards of PN-B-03264 [4] and PN-S 10042 [5]. The grade B500SP means that the steel is intended for use in construction (B), with the characteristic yield stress of $500 \mathrm{MPa}$, weldable steel (S), and with increased ductility $(\mathrm{P})$.

\footnotetext{
${ }^{1}$ Prof., DSc., PhD., Eng., Opole University of Technology, Faculty of Civil Engineering, Katowicka 48, 45-061 Opole, Poland, e-mail: t.chmielewski@po.opole.pl

${ }^{2}$ MSc in Civ. Eng., Steel Quality Promotion Center, Witolda Pileckiego 67, 02-781 Warsaw, Poland, e-mail: mpiotrowska@cpjs.pl
} 
EPSTAL steel is characterized by the following mechanical properties:

- strength and strain parameters characterized by high stability,

- resistance to dynamic loads: fatigue and cyclic,

- bending resistance with deflecting,

- very good bond to concrete,

- weldability in the full range of bar diameters, i.e. from 8 to $40 \mathrm{~mm}$.

The static tensile test is the basic method for determining the strength and strain properties of steel. Full information on the principle of performing the tensile test of steel, the shape and dimensions of the samples with the determination of the test parameters, i.e. the values of strength, elongation, and narrowing of the samples along with what the test report should contain, is given in the standard PN-EN ISO 6892-1 [6]

The purpose of this article is to examine the variability of strength and elongation parameters of EPSTAL steel produced in Polish steelworks, i.e. the yield stress $R_{e}$, tensile strength $R_{m}$, and elongation $\mathrm{A}_{\mathrm{gt}}$ under the highest load. Our study is based on fundamental engineering static roomtemperature tensile tests for large series specimens which have been made by manufacturers as the part of a factory quality control. Statistical analysis of these results showed that the stress-strain relationship of steel tensile tests should be described, in the terms of probability theory, as a one-dimensional stochastic process and three the most important mechanical parameters, i.e. the yield stress, tensile strength, and elongation under the highest load, as random variables. Based on the statistical elaboration of experimental data, it was found, that the yield stress and tensile strength of steel bars produced in the years 2016 - 2017 had the coefficients of variation less than $3 \%$, and there is a reasonable basis for the manufacturer to increase the characteristic value of the steel bars yield stress by a few percentage.

\section{TENSILE TEST OF EPSTAL STEEL AS A RANDOM PHENOMENON DESCRIBED BY A ONE-DIMENSIONAL STOCHASTIC PROCESS}

Let us consider an experiment, in which some number (n) of EPSTAL steel specimens of the same diameter is tested to determine their mechanical properties (a static tensile test). For example, for a reinforcing rod with a diameter of $16 \mathrm{~mm}$, after testing ten samples, the following results for the yield stress, tensile strength, and elongation under the highest load are presented in Table 1. 
A question arises: which values should be considered as the yield stress, tensile strength, and elongation under the highest load? For such the question, there is no answer in a set of deterministic quantities, i.e. in a set of quantities that are exactly known. Such the question can be answered only in a set of probabilistic concepts, i.e. using the concepts of the probability theory, which describes random phenomena. Observing such phenomena, we state that in a given test the actual outcomes are (to some degree) unpredictable. Such phenomena are characterized by experimental observations, that are invariably different from one test to another (even if performed under identical conditions). In the case of EPSTAL steel, the main sources of variation in the values of the mechanical parameters $\mathrm{R}_{\mathrm{e}}, \mathrm{R}_{\mathrm{m}}$, and $\mathrm{A}_{\mathrm{gt}}$ are:

- the variability of the material properties for the production of ingots, i.e. scrap and ferroalloys (especially the variability of the chemical composition of scrap metal is of decisive importance here and is reflected in the property variation),

- in the rolling process: the temperature distribution of the ingot on its length and variability of water parameters in controlled cooling after the last rolling stand (pressure and flow).

Table 1. The yield stress, tensile strength, and maximum elongation for 10 static tensile tests of 16 $\mathrm{mm}$ diameter rods

\begin{tabular}{|c|c|c|}
\hline $\mathrm{R}_{\mathrm{e}}[\mathrm{MPa}]$ & $\mathrm{R}_{\mathrm{m}}[\mathrm{MPa}]$ & $\mathrm{A}_{\mathrm{gt}}[\%]$ \\
\hline 535 & 621 & 14,5 \\
\hline 539 & 631 & 15 \\
\hline 539 & 636 & 14 \\
\hline 535 & 638 & 13,1 \\
\hline 555 & 652 & 14,3 \\
\hline 566 & 652 & 13,1 \\
\hline 538 & 636 & 13 \\
\hline 535 & 635 & 13,4 \\
\hline 548 & 638 & 15,6 \\
\hline 553 & 646 & 15,1 \\
\hline
\end{tabular}

It is possible to control these variations only within certain limits, e.g. by adjusting the water flow to obtain the most uniform strength properties and additionally by setting the appropriate ingot heating strategy to reduce the temperature spread over the band-length. After one tensile test of the steel sample, we obtain a stress-strain diagram which is recorded with the function $\sigma(\varepsilon)$. Let us consider the experiment, in which we made 15 tensile tests of steel specimens, and received 15 
stress-strain diagrams. Let us assume that we compiled these charts in one common drawing shown in Fig. 1. From this figure, we conclude that the graphs do not overlap with uncertain, accidental discrepancies between them. Therefore, at the present stage of knowledge, tensile tests of steel samples and stress-strain diagrams derived from them should be described with a one-dimensional stochastic process, which mathematically describes the relationship $\sigma(\varepsilon, \mathrm{e})$, where e is an elementary event consisting in a tensile test of a steel specimen.

From an engineering point of view, the following interpretation of the stochastic process $\sigma(\varepsilon, \mathrm{e})$ is preferable (Ang and Tang [7], Chmielewski [8]):

a) let us suppose that the elementary event $e_{1}$ occurred, i.e. we made the tensile test on one specimen and received the function $\sigma\left(\varepsilon, \mathrm{e}_{1}\right)=\sigma(\varepsilon)$ (because $\mathrm{e}_{1}$ is fixed) which we call the implementation of the stochastic process. After doing $n$ tensile tests we get $n$ implementations of the process. Example 15 of implementations are shown in Fig. 1,

b) let $\varepsilon$ be determine, e.g. $\varepsilon=1 \%$, and e is variable. Then we get a cross-section of the process which is a random variable. Two sections are important for construction engineers, the first for the yield stress Re, the second for the tensile strength Rm,

c) let $\varepsilon$ be determine and e determine, then we only get a number, that we call the state of the process.

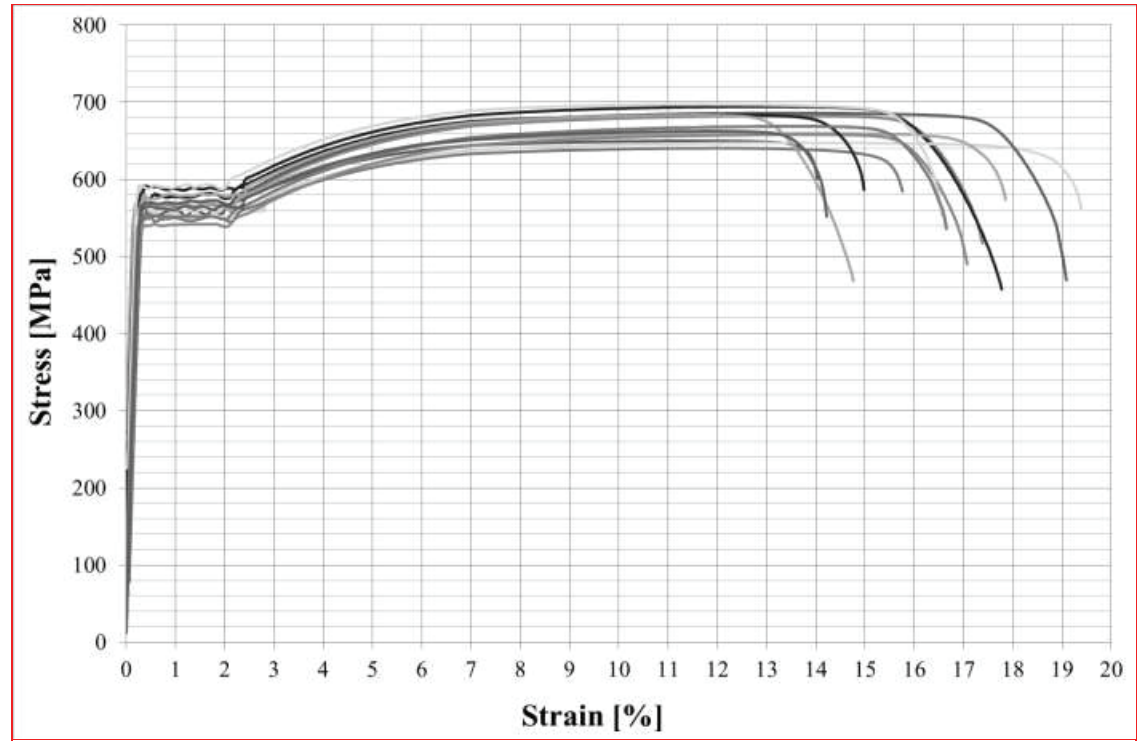

Fig. 1 The collection of stress-strain diagrams for 15 steel samples subjected to the tensile test, which constitutes 15 implementations of the stochastic process $\sigma(\varepsilon, \mathrm{e})$ 


\section{EXPERIMENTAL STUDIES OF RANDOM VARIABLES $\mathbf{R}_{E}, \mathbf{R}_{M}$ AND $A_{G T}$, THEIR HISTOGRAMS AND NUMERICAL PARAMETERS}

The full probabilistic descriptions of the continuous random variables $R_{e}, R_{m}$, and $A_{g t}$ are their probability distributions, i.e. cumulative distribution functions or probability density functions. If they are known, on their basis we can calculate the probabilities of possible events, as well as main descriptors of random variables, e.g. mean values, variances, standard deviations, etc.

In order to learn the aforementioned values and properties, it is necessary to collect experimental data which in our case is performed by producers as part of factory quality control. For the authors, the above data is the basis for statistical inference for the needs of civil engineers.

Statistical inference includes the following steps:

- collecting $\mathrm{n}$ experimental data for each random variable which we call a trial,

- preparing histograms and calculating selected main descriptors for them,

- adopting the theoretical probability distribution and conducting its verification on the basis of statistical tests.

In order to investigate the variability of the strength and elongation parameters of EPSTAL steel reinforcing bars, the following assumption regarding the number of samples was adopted. The number of static tensile tests of bar samples with the same diameters made in a specific year was taken for the number of samples and the histograms were constructed for them, on the basis of which the selected estimators of main descriptors were calculated. For example, Figs. 3, 5, and 7 show histograms of yield stress, tensile strength and elongation under the highest load of reinforcing bar of diameter $=16 \mathrm{~mm}$ produced in 2016, where $\mathrm{n}$ is the sample size, $\overline{R_{e}}, \overline{R_{m}}$, and $\overline{A_{g t}}$ are the average values of the trial, $\mathrm{s}$ is the standard deviation of the trial, $v$ is the coefficient of variation of the trial, $R_{e}, 5 \%$ is the experimental characteristic value, $R_{e m i n}$ is the smallest value of the trial, $R_{\text {emax }}$ is the largest value of the trial. Figs. 4, 6, and 8 show histograms with the same main descriptors for reinforcing bar of diameter $=16 \mathrm{~mm}$, but produced in 2017. Figs. 9 and 10 show histograms with their main descriptors for reinforcing bars for all their diameters, i.e. 10, 12, 16, 20 , $25,28,32 \mathrm{~mm}$. 


\section{CHARACTERISTIC VALUES OF THREE RANDOM VARIABLES $\mathbf{R}_{\mathrm{E}}, \mathbf{R}_{\mathrm{M}}$, AND A $A_{G T}$ OF EPSTAL STEEL}

The standard PN-EN 1990 (2004) which is the basic standard of construction engineers, in Section 4.2 "Properties of materials and products" gives the following definitions of material properties:

(1) It is recommended that the material properties (including soil and rock) or products are determined by their characteristic properties.

(2) Unless otherwise stated in EN 1991 to EN 1999: when the lower material value is unfavorable, the characteristic value is to be set as $5 \%$ quantile.

On the basis of the above mentioned standard, the characteristic strength of random variables of yield stress and tensile strength which we refer to as $R_{e, 5 \%}$ and $R_{m, 5 \%}$, is defined as follows: "these are strength values below which $5 \%$ of the population of all possible strength determinations can be found", i.e. the values of both strengths achieved by a minimum of $95 \%$ of the samples tested for a given series of trials . In a similar way, we define the characteristic value of the variable of the elongation Agt. From the probability calculus, the characteristic value of the continuous random variable $F$ is defined precisely as the quantile of $0.05(5 \%)$. For the probability density function $p_{F}(f)$ the characteristic value is defined as

$$
\int_{-\infty}^{F, 5 \%} p_{F}(f) d f=0.05
$$

Graphical interpretation of Eq. (1) is shown in Fig. 2.

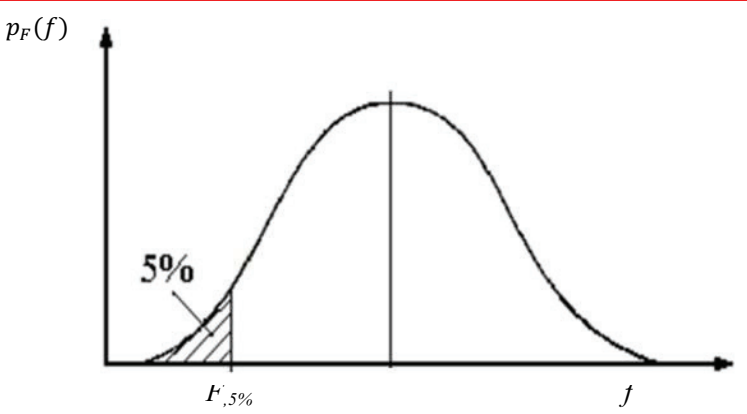

Fig. 2 Probability density function $p_{F}(f)$ of the random variable $F$ with the indication of its characteristic value $F_{, 5 \%}$ 

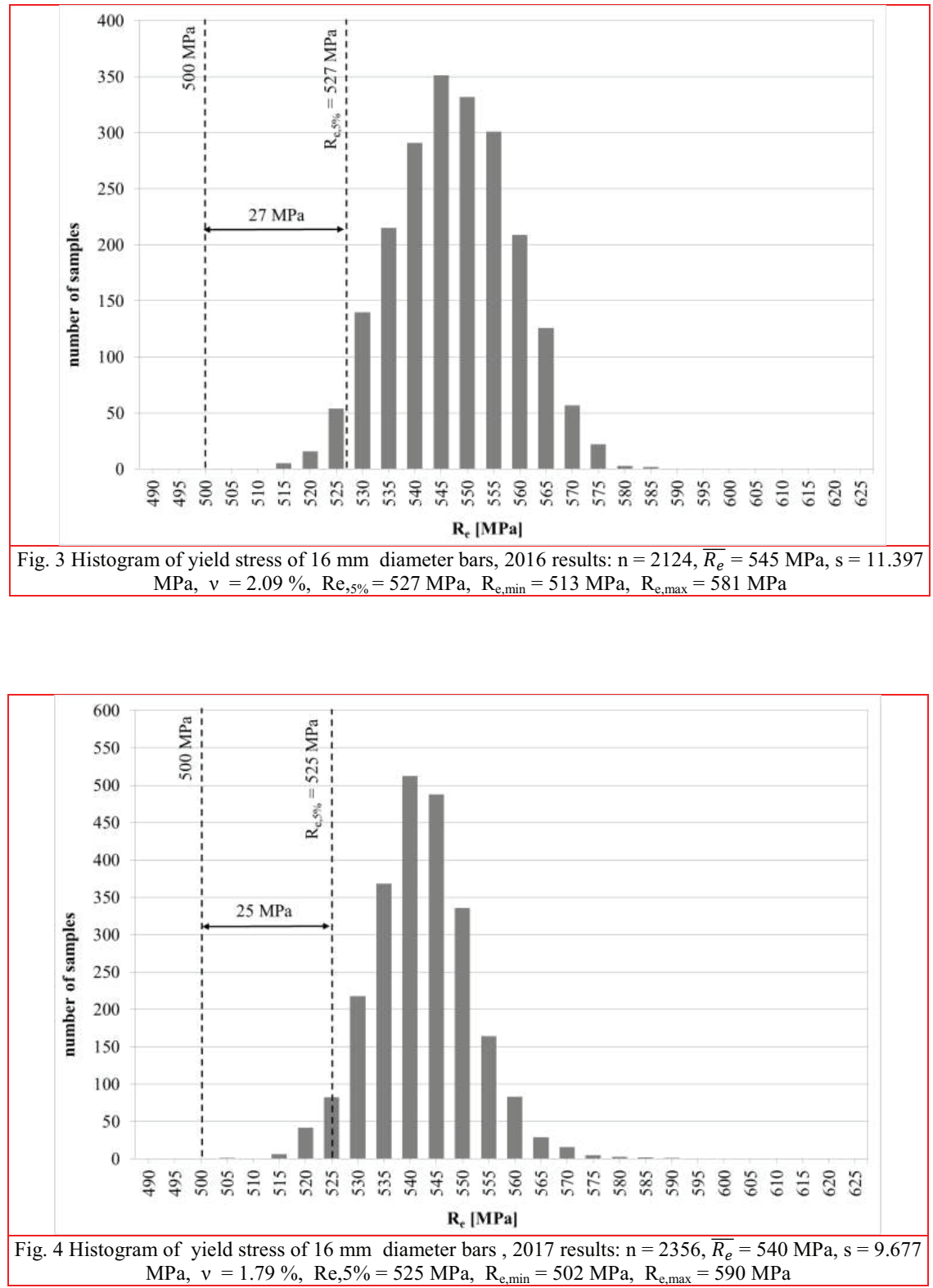

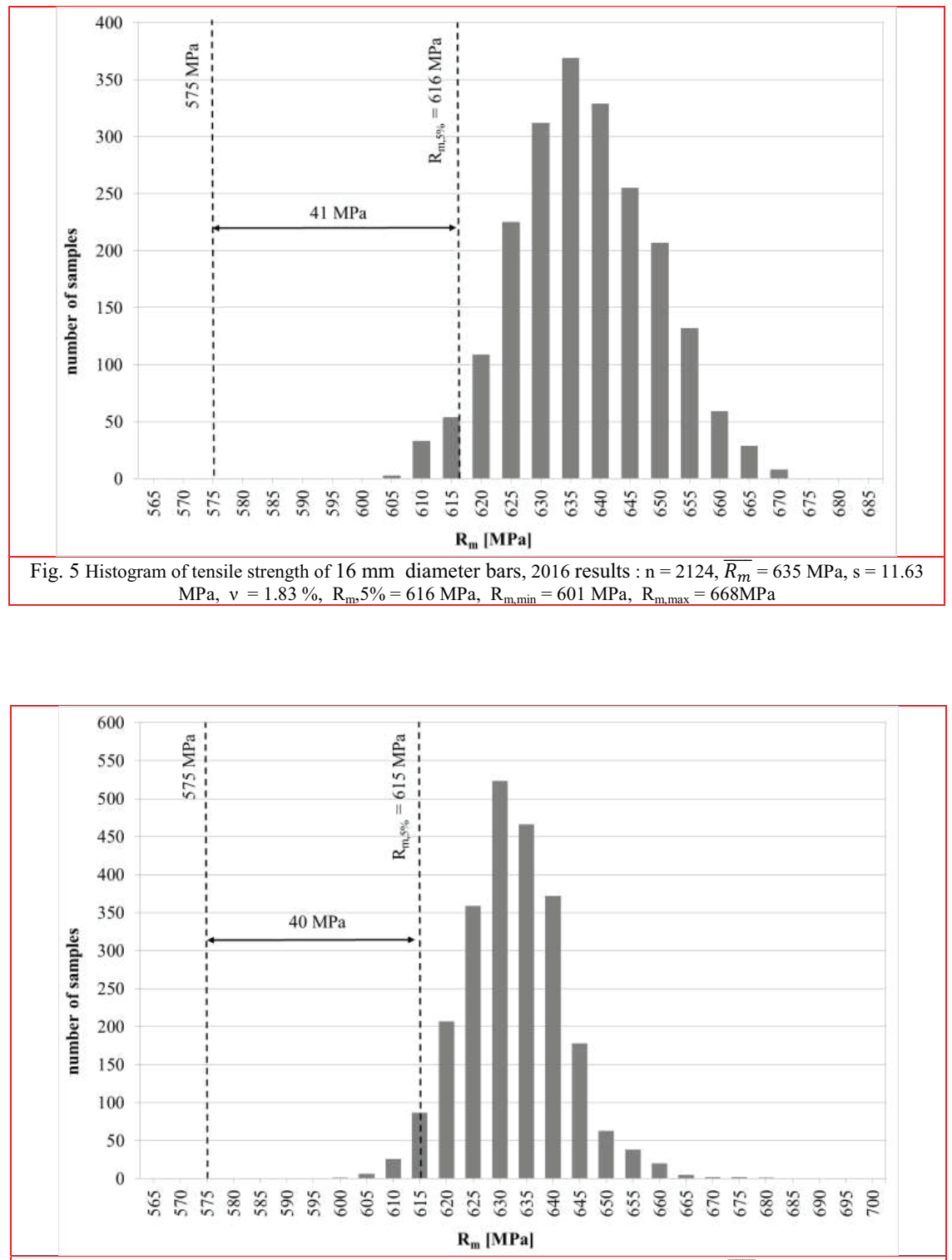

Fig. 6 Histogram of tensile strength of $16 \mathrm{~mm}$ diameter bars, 2017 results $: \mathrm{n}=2356, \overline{R_{m}}=631 \mathrm{MPa}, \mathrm{s}=9.523$ $\mathrm{MPa}, v=1.51 \%, \mathrm{Rm}_{, 5 \%}=615 \mathrm{MPa}, \mathrm{R}_{\mathrm{m}, \min }=599 \mathrm{MPa}, \mathrm{R}_{\mathrm{m}, \text { max }}=678 \mathrm{MPa}$ 


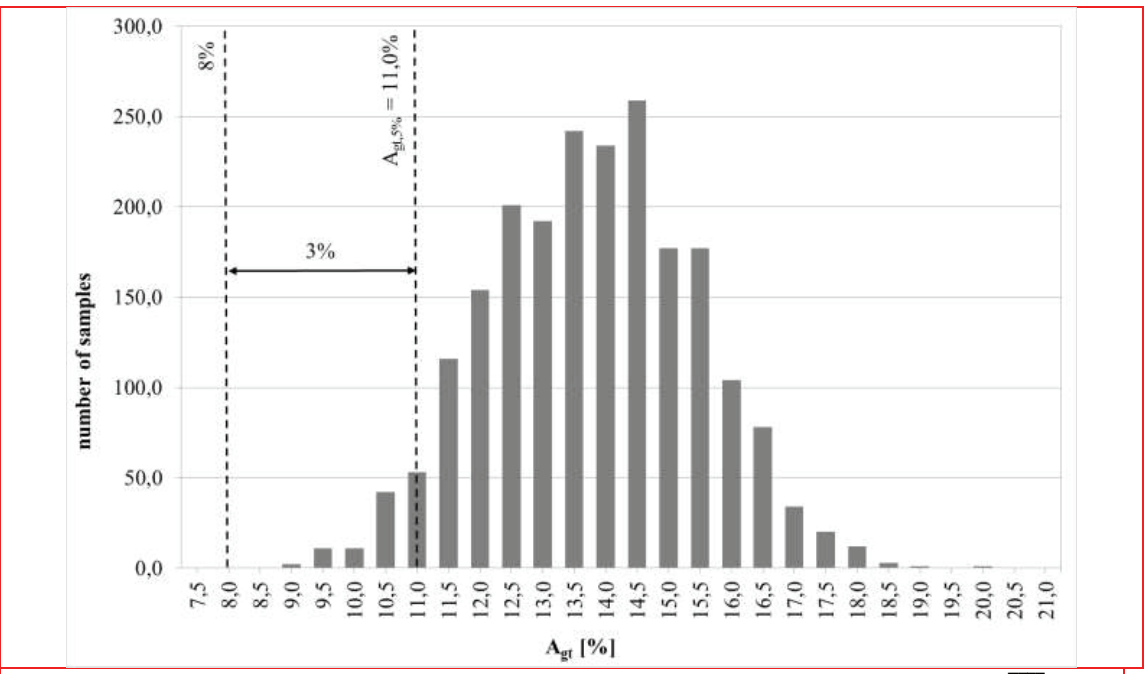

Fig. 7 Histogram of elongation of $16 \mathrm{~mm}$ diameter bars under the highest load, 2016 results: $\mathrm{n}=2124, \overline{A_{g t}}=13.60$ $\%, \mathrm{~s}=1.65 \%, \mathrm{v}=12.10 \%, \mathrm{Agt}, 5 \%=11.0 \%, \mathrm{~A}_{\mathrm{gt} \text {,min }}=8,7, \mathrm{~A}_{\mathrm{gt}, \max }=19.8 \%$

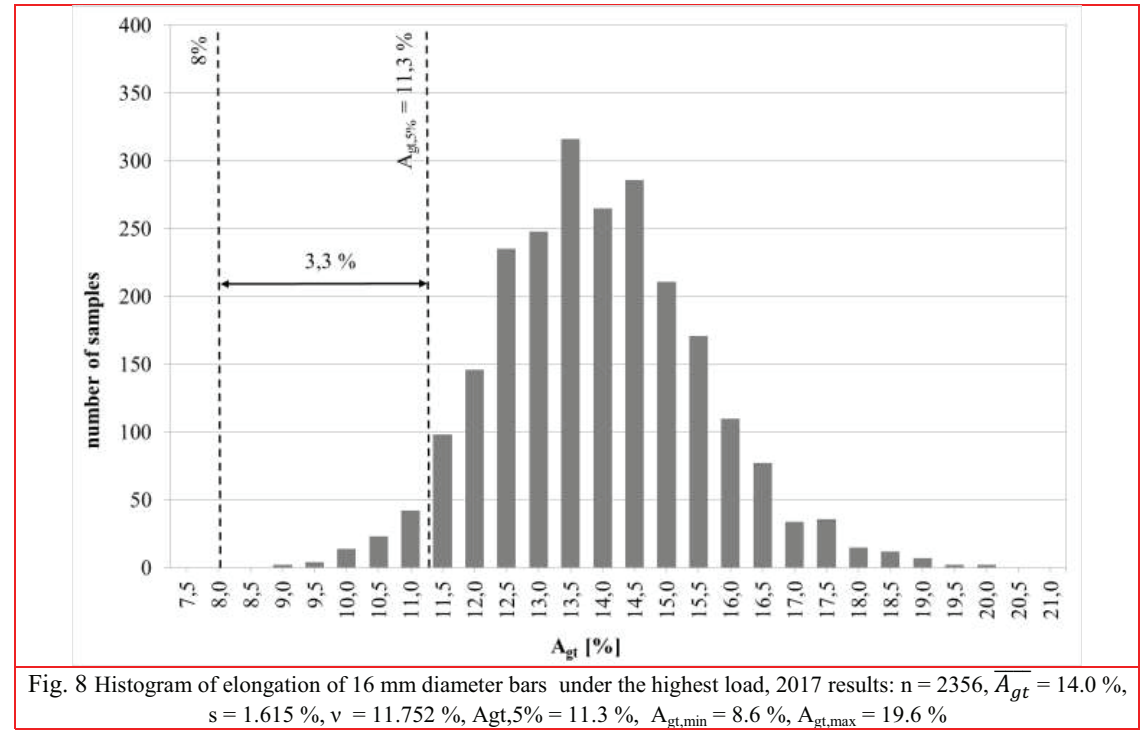




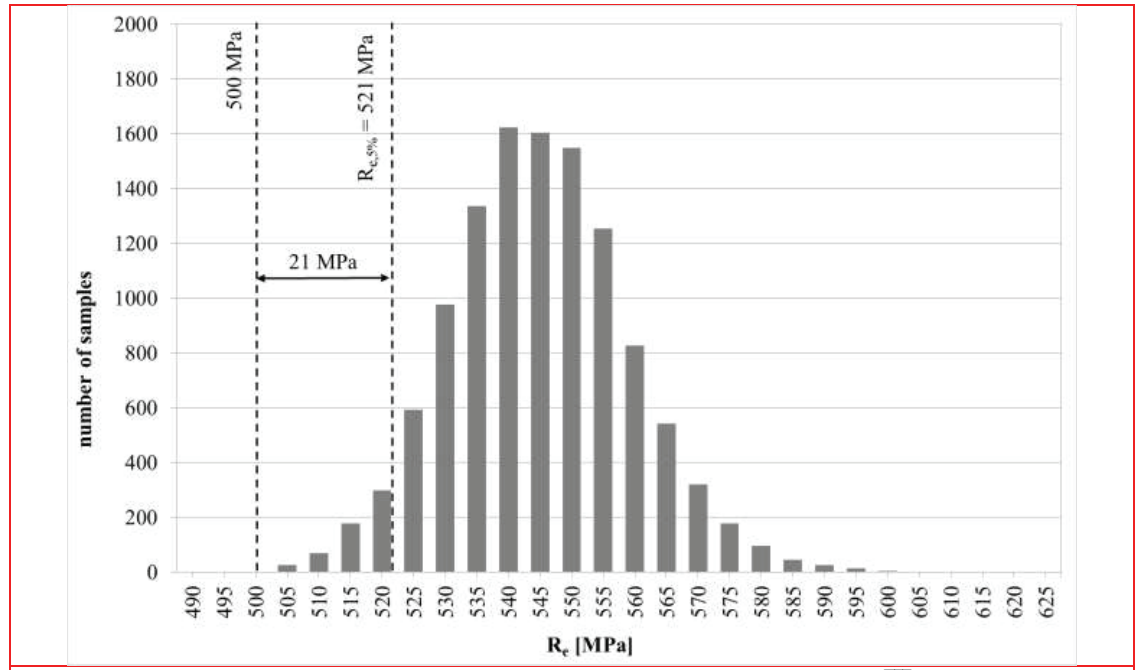

Fig. 9 Histogram of the yield stress of bars (diameters $10-32 \mathrm{~mm}$ ), 2016 results: $\mathrm{n}=11570, \overline{R_{e}}=543 \mathrm{MPa}, \mathrm{s}=14.18$ $\mathrm{MPa}, v=2.61 \%, \mathrm{Re}, 5 \%=521 \mathrm{MPa}, \mathrm{R}_{\mathrm{e}, \min }=500 \mathrm{MPa}, \mathrm{R}_{\mathrm{e}, \max }=608 \mathrm{MPa}$

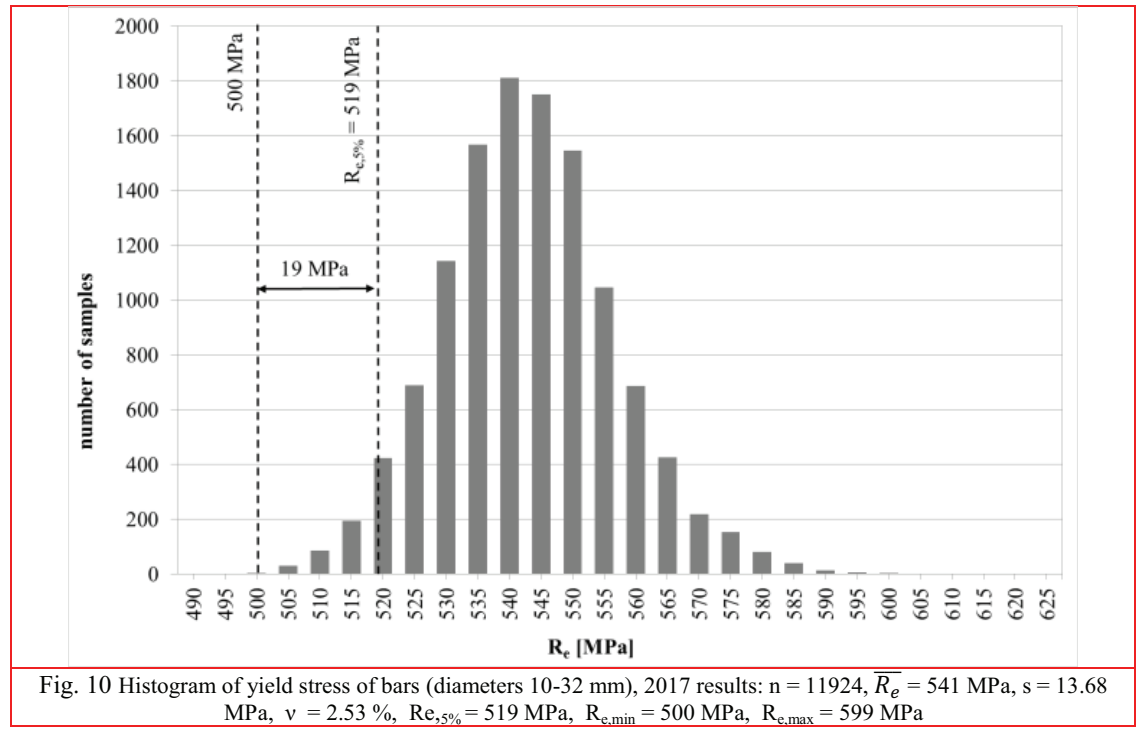

Histograms of the yield stress, tensile strength and elongation under the highest load for reinforcing steel bars of other diameters, i.e. 10, 12, 20, 25, 28, and $32 \mathrm{~mm}$, were also constructed, and their main descriptors were calculated. Yield stress experimental descriptors are presented in Table 2. 
Table 2. The experimental values of the yield stress for bars with different diameters and collected for all diameters

\begin{tabular}{|c|c|c|c|c|c|c|c|}
\hline Diameter & $\mathrm{n}$ & $\overline{R_{e}}$ & $\mathrm{~s}$ & $v$ & $\operatorname{Re}, 5 \%$ & $R_{e, \text { min }}$ & $\mathrm{R}_{\mathrm{e}, \max }$ \\
\hline \multicolumn{8}{|c|}{2016 year } \\
\hline $10 \mathrm{~mm}$ & 1836 & 543 & 14.18 & 2.61 & 521 & 500 & 608 \\
\hline $12 \mathrm{~mm}$ & 3537 & 540 & 13.33 & 2.47 & 520 & 500 & 608 \\
\hline $16 \mathrm{~mm}$ & 2124 & 545 & 11.40 & 2.09 & 527 & 513 & 581 \\
\hline $20 \mathrm{~mm}$ & 1777 & 539 & 11.86 & 2.20 & 519 & 503 & 574 \\
\hline $25 \mathrm{~mm}$ & 1405 & 552 & 13.57 & 2.46 & 531 & 510 & 598 \\
\hline $28 \mathrm{~mm}$ & 338 & 547 & 13.75 & 2.51 & 524 & 504 & 593 \\
\hline $32 \mathrm{~mm}$ & 446 & 557 & 11.82 & 2.12 & 536 & 525 & 586 \\
\hline $10-32 \mathrm{~mm}$ & 11570 & 543 & 14.18 & 2.61 & 521 & 500 & 608 \\
\hline \multicolumn{8}{|c|}{2017 year } \\
\hline $10 \mathrm{~mm}$ & 1776 & 539 & 15.48 & 2.87 & 514 & 500 & 598 \\
\hline $12 \mathrm{~mm}$ & 3870 & 537 & 13.68 & 2.54 & 517 & 502 & 596 \\
\hline $16 \mathrm{~mm}$ & 2356 & 540 & 9.68 & 1.79 & 525 & 502 & 590 \\
\hline $20 \mathrm{~mm}$ & 1712 & 540 & 12.13 & 2.25 & 521 & 505 & 597 \\
\hline $25 \mathrm{~mm}$ & 1184 & 550 & 9.69 & 1.76 & 534 & 518 & 589 \\
\hline $28 \mathrm{~mm}$ & 260 & 557 & 9.32 & 1.67 & 542 & 536 & 599 \\
\hline $32 \mathrm{~mm}$ & 603 & 553 & 15.08 & 2.73 & 528 & 505 & 591 \\
\hline $10-32 \mathrm{~mm}$ & 11924 & 541 & 13.68 & 2.53 & 519 & 500 & 599 \\
\hline
\end{tabular}




\section{CONCLUSiOnS}

EPSTAL steel producers perform static tensile tests of steel samples thousands of times per year (several hundred times for some diameters) as part of the factory quality control. These are multiple tests, repeated under the same room-temperature conditions, giving different results. There is, therefore, a full basis for a probabilistic description of the mechanical parameters of EPSTAL steel bars which are presented in this paper. On the basis of statistical elaboration of data concerning these parameters from the last two years, i.e. 2016 and 2017, the following conclusions were formulated:

1. The tensile testing phenomenon of EPSTAL steel samples should be described by a one-dimensional non-stationary stochastic process $\sigma(\varepsilon, \mathrm{e})$.

2. Mechanical properties of steel rods, i.e. the yield stress, tensile strength, and elongation should be described with continuous random variables. The histograms of these parameters, for individual diameters and static tensile tests recorded in the years 2016 - 2017 were constructed. For the purpose of illustration, several histograms are shown in Figs. 3 through 10. The estimators of the main descriptors of these three random variables were also calculated. Yield stress experimental descriptors, for rods with different diameters and collectively for all diameters, are presented in Table 2 .

3. The coefficients of variation of the yield stress of bars with diameters from 10 to $32 \mathrm{~mm}$, produced in the years 2016 - 2017, assumed values in the range: $2.09-2.61 \%$ for 2016 and $1.79-2.87 \%$ for 2017 . These are small values, i.e. the variability of the yield stress results is small. The steel produced is of very good quality.

4. The coefficients of variation of the tensile strength of bars with diameters from 10 to $32 \mathrm{~mm}$, produced in the years 2016 - 2017, assumed values in the range: $1.60-2.24 \%$ for 2016 and $1.43-2.28 \%$ for 2017 . These are small values, i.e. the variability of the tensile strength results is small.

5. The experimental characteristic values of the yield stress, i.e. $R_{e, 5 \%}$, are in the range from 519 to 536 $\mathrm{MPa}$ in 2016 and from 514 to $542 \mathrm{MPa}$ in 2017. The current characteristic value adopted by the manufacturer at the level of $500 \mathrm{MPa}$ is undervalued, for bars with a diameter of $10 \mathrm{~mm}$ by around $3 \%$, and for bars with a diameter of $16 \mathrm{~mm}$ or more - by $5 \%$ to even $6 \%$.

\section{ACKNOWLEDGMENTS}

The writers are grateful for Polish EPSTAL steel producers that performed static tensile tests of steel specimens - thousands of time per year in 2016 and 2017 as part of the factory quality control. The writers also wish to acknowledge the Opole University of Technology and Steel Quality Promotion Center for their support of the project. 


\section{REFERENCES}

1. PN-H-93220 B500SP (2018): Steel with increased ductility for concrete reinforcement. Rods and ribbed wire rod, Polish Standard (in Polish).

2. PN-EN 10080 (2007): Steel for the reinforcement of concrete. Weldable reinforcing steel. General, Polish Standard (in Polish).

3. EN (1992). Eurocode 2: Design of concrete structures.

4. PN-B-03264 (2002). Concrete, reinforced concrete, and prestressed structures. Static calculations and design, Polish Standard (in Polish).

5. PN-S 10042, 1991. Bridge structures. Concrete, reinforced concrete, and prestressed constructions. Designing. Polish Standard (in Polish).

6. PN-EN ISO 6892-1 (2016): Metals. Tensile test. Part 1: Test method at room temperature, Polish Standard (in Polish).

7. A.H-S. Ang, W. H.Tang, "Probability Concepts in Engineering Planning and Design", John Wiley \& Sons, New York, 1984.

8. T. Chmielewski, „Probabilistic methods in dynamics of structures”, Wyższa Szkoła Inżynierska w Opolu, Studia i Monografie z.1, Opole, Poland, 1982 (in Polish).

9. PN (2004) EN :1990. Eurocode 1, Basics of structural design. Polish Standard (in Polish).

\section{LIST OF FIGURES AND TABLES}

Fig. 1. The collection of stress-strain diagrams for 15 steel samples subjected to the tensile test, which constitutes 15 implementations of the stochastic process $\sigma(\varepsilon, \mathrm{e})$

Rys. 1. Zbiór 15 wykresów naprężenie-odkształcenie próbek stalowych poddanych rozciąganiu. Stanowią one 15 realizacji procesu stochastycznego $\sigma(\varepsilon, \mathrm{e})$

Fig. 2. Probability density function $p_{F}(f)$ of the random variable $F$ with the indication of its characteristic value $F_{, 5 \%}$

Rys. 2. Funkcja gęstości prawdopodobieństwa $p_{F}(f)$ zmiennej losowej $F$ ze wskazaniem wartości charakterystycznej $F, 5 \%$

Fig. 3 Histogram of yield stress of $16 \mathrm{~mm}$ diameter bars, 2016 results: $\mathrm{n}=2124, \overline{R_{e}}=545 \mathrm{MPa}, \mathrm{s}=$ $11.397 \mathrm{MPa}, v=2.09 \%, \mathrm{Re}_{5 \%}=527 \mathrm{MPa}, \mathrm{Re}_{\min }=513 \mathrm{MPa}, \mathrm{Re}_{\max }=581 \mathrm{MPa}$

Rys.3. Histogram granicy plastyczności prętów o średnicy $16 \mathrm{~mm}$, wyniki $2016: \mathrm{n}=2124, \overline{R_{e}}=545$ $\mathrm{MPa}, \mathrm{s}=11.397 \mathrm{MPa}, v=2.09 \%, \mathrm{Re}, 5 \%=527 \mathrm{MPa}, \mathrm{Re}_{\min }=513 \mathrm{MPa}, \mathrm{Re}_{\max }=581 \mathrm{MPa}$

Fig. 4 Histogram of yield stress of $16 \mathrm{~mm}$ diameter bars , 2017 results: $\mathrm{n}=2356, \overline{R_{e}}=540 \mathrm{MPa}, \mathrm{s}$ $=9.677 \mathrm{MPa}, v=1.79 \%, \mathrm{Re}, 5 \%=525 \mathrm{MPa}, \mathrm{Re}_{\min }=502 \mathrm{MPa}, \mathrm{Re}_{\max }=590 \mathrm{MPa}$

Rys. 4. Histogram granicy plastyczności prętów o średnicy $16 \mathrm{~mm}$, wyniki $2017: \mathrm{n}=2356, \overline{R_{e}}=$ $540 \mathrm{MPa}, \mathrm{s}=9.677 \mathrm{MPa}, v=1.79 \%, \mathrm{Re}, 5 \%=525 \mathrm{MPa}, \mathrm{Re}_{\min }=502 \mathrm{MPa}, \mathrm{Re}_{\max }=590 \mathrm{MPa}$

Fig. 5 Histogram of tensile strength of $16 \mathrm{~mm}$ diameter bars, 2016 results $: \mathrm{n}=2124, \overline{R_{m}}=635$ $\mathrm{MPa}, \mathrm{s}=11.63 \mathrm{MPa}, v=1.83 \%, \mathrm{Rm}, 5 \%=616 \mathrm{MPa}, \mathrm{Rm}_{\min }=601 \mathrm{MPa}, \mathrm{Rm}_{\max }=668 \mathrm{MPa}$

Rys. 5. Histogram wytrzymałości na rozciąganie prętów średnicy16 mm, wyniki 2016: $\mathrm{n}=2124$, $\overline{R_{m}}=635 \mathrm{MPa}, \mathrm{s}=11.63 \mathrm{MPa}, v=1.83 \%, \mathrm{Rm}, 5 \%=616 \mathrm{MPa}, \mathrm{Rm}_{\min }=601 \mathrm{MPa}, \mathrm{Rm}_{\max }=$ $668 \mathrm{MPa}$ 
Fig. 6 Histogram of tensile strength of $16 \mathrm{~mm}$ diameter bars, 2017 results $: \mathrm{n}=2356, \overline{R_{m}}=631$ $\mathrm{MPa}, \mathrm{s}=9.523 \mathrm{MPa}, v=1.51 \%, \mathrm{Rm}, 5 \%=615 \mathrm{MPa}, \mathrm{Rm}_{\min }=599 \mathrm{MPa}, \mathrm{Rm}_{\max }=678 \mathrm{MPa}$

Rys. 6. Histogram wytrzymałości na rozciąganie prętów średnicy16 mm, wyniki 2017: $\mathrm{n}=2356$, $\overline{R_{m}}=631 \mathrm{MPa}, \mathrm{s}=9.523 \mathrm{MPa}, v=1.51 \%, \mathrm{Rm}, 5 \%=615 \mathrm{MPa}, \mathrm{Rm}_{\min }=599 \mathrm{MPa}, \mathrm{Rm}_{\max }=$ $678 \mathrm{MPa}$

Fig. 7 Histogram of elongation of $16 \mathrm{~mm}$ diameter bars under the highest load, 2016 results: $\mathrm{n}=$ $2124, \overline{A_{g t}}=13.60 \%, \mathrm{~s}=1.65 \%, v=12.10 \%, \mathrm{Agt}, 5 \%=11.0 \%$, Agt ${ }_{\min }=8,7, \mathrm{Agt}_{\text {, } \max }=19.8 \%$

Rys. 7. Histogram wydłużenia prętów średnicy $16 \mathrm{~mm}$, wyniki 2016: : $\mathrm{n}=2124, \overline{A_{g t}}=13.60 \%$, s $=$ $1.65 \%, v=12.10 \%$, Agt, $5 \%=11.0 \%$, Agt $_{\text {min }}=8,7$, Agt $_{\text {max }}=19.8 \%$

Fig. 8. Histogram of elongation of $16 \mathrm{~mm}$ diameter bars under the highest load, 2017 results: $\mathrm{n}=$ $2356, \overline{A_{g t}}=14.0 \%, \mathrm{~s}=1.615 \%, v=11.752 \%, \mathrm{Agt}, 5 \%=11.3 \%, \mathrm{Agt}_{\min }=8.6 \%, \mathrm{Agt}_{\text {max }}=19.6$ $\%$

Rys.8. Histogram wydłużenia prętów średnicy $16 \mathrm{~mm}$, wyniki 2017: $\mathrm{n}=2356, \overline{A_{g t}}=14.0 \%, \mathrm{~s}=$ $1.615 \%, v=11.752 \%$, Agt, $5 \%=11.3 \%$, Agt, ${ }_{\text {min }}=8.6 \%$, Agt $_{\text {max }}=19.6 \%$

Fig. 9 Histogram of the yield stress of bars (diameters 10-32 mm), 2016 results: $\mathrm{n}=11570, \overline{R_{e}}=$ $543 \mathrm{MPa}, \mathrm{s}=14.18 \mathrm{Mpa}, v=2.61 \%, \operatorname{Re}, 5 \%=521 \mathrm{Mpa}, \mathrm{Re}_{\min }=500 \mathrm{Mpa}, \operatorname{Re}_{\max }=608 \mathrm{Mpa}$ Rys. 9. Histogram granicy plastyczności prętów o średnicach 10-32 mm, wyniki 2016: $\mathrm{n}=11570$, $\overline{R_{e}}=543 \mathrm{MPa}, \mathrm{s}=14.18 \mathrm{Mpa}, v=2.61 \%, \mathrm{Re}, 5 \%=521 \mathrm{Mpa}, \mathrm{Re}_{\min }=500 \mathrm{Mpa}, \mathrm{Re}_{\max }=608$ $\mathrm{Mpa}$

Fig. 10 Histogram of yield stress of bars (diameters $10-32 \mathrm{~mm}$ ), 2017 results: $\mathrm{n}=11924, \overline{R_{e}}=541$ $\mathrm{MPa}, \mathrm{s}=13.68 \mathrm{Mpa}, v=2.53 \%, \mathrm{Re}_{5 \%}=519 \mathrm{Mpa}, \mathrm{Re}_{\min }=500 \mathrm{Mpa}, \mathrm{Re}_{\max }=599 \mathrm{Mpa}$

Rys. 10. Histogram granicy plastyczności prętów o średnicach 10-32 mm, wyniki 2017: $\mathrm{n}=11924$, $\overline{R_{e}}=541 \mathrm{MPa}, \mathrm{s}=13.68 \mathrm{Mpa}, v=2.53 \%, \mathrm{Re}, 5 \%=519 \mathrm{Mpa}, \mathrm{Re}_{\min }=500 \mathrm{Mpa}, \operatorname{Re}_{\max }=599$ Mpa

Tab. 1. The yield stress, tensile strength, and maximum elongation for 10 static tensile tests of 16 mm diameter bars

Tab. 1. Wartości granicy plastyczności, wytrzymałości na rozciąganie i wydłużenia dla 10 próbek stalowych średnicy $16 \mathrm{~mm}$

Tab. 2. The experimental values of the yield stress for bars with different diameters and collected for all diameters

Tab. 2. Eksperymentalne wartości granicy plastyczności dla prętów o różnej średnicy i dla prętów o średnicach 10-32 mm 


\title{
BADANIE ZMIENNOŚCI PARAMETRÓW WYTRZYMALOŚCIOWYCH STALI EPSTAL
}

Slowa kluczowe: Stal EPSTAL, proces stochastyczny, parametry wytrzymałościowe, zmienne losowe, histogramy.

\section{SUMMARY:}

\begin{abstract}
1. Wstęp
Przedmiotem niniejszego artykułu jest zbadanie zmienności parametrów wytrzymałościowych stali EPSTAL produkowanej w polskich hutach, tj. granicy plastyczności $R_{e}$, wytrzymałości na rozciąganie $R_{m} i$ wydłużenia pod największym obciążeniem $\mathrm{A}_{\mathrm{g}}$, na podstawie wyników statycznej próby rozciągania próbek stali wykonanej przez producentów w ramach zakładowej kontroli produkcji. Analiza statystyczna tych wyników wykazała, że zależność naprężenie-odkształcenie prób rozciągania stali należy opisać w języku rachunku prawdopodobieństwa jako jednowymiarowy proces stochastyczny, zaś trzy najważniejsze parametry wytrzymałościowe: granicę plastyczności, wytrzymałość na rozciąganie i wydłużenie pod największym obciążeniem, jako zmienne losowe. Na podstawie opracowania danych eksperymentalnych stwierdzono, że granica plastyczności i wytrzymałość na rozciąganie prętów produkowanych w latach 2016 - 2017 mają współczynniki zmienności na poziomie mniejszym niż 3\%, ponadto istnieje uzasadniona podstawa, aby producent podwyższył wartość charakterystyczną granicy plastyczności prętów stalowych o kilka procent.
\end{abstract}

\section{Materiały i metody}

W celu zbadania zmienności parametrów wytrzymałościowych prętów zbrojeniowych stali EPSTAL przyjęto następujące założenie dotyczące liczebności prób. Za liczebność próby przyjęto liczbę statycznych prób rozciągania próbek prętów o jednakowych średnicach $(10,12,14,16,20$, 25, 28 i $32 \mathrm{~mm})$ wykonanych w ciągu jednego roku. Dla tak przyjętej liczby prób sporządzono histogramy dla trzech zmiennych losowych, tj. granicy plastyczności, wytrzymałości na rozciąganie i wydłużenia dla wszystkich produkowanych średnic i produkcji prętów w latach $2016 \mathrm{i}$ 2017.

\section{Wyniki}

$\mathrm{Na}$ podstawie sporządzonych histogramów obliczono następuj estymatory liczbowe: wartości średnie próby $\overline{R_{e}}, \overline{R_{m}} \mathrm{i}$ $\overline{A_{g t}}$, odchylenia standardowym próby (s) i współczynniki zmienności próby (v). Na histogramach podano także liczebność każdej próby (n), najmniejszą wartością próby i największą wartością próby.

\section{Wnioski}

Na podstawie przeprowadzonych badań i ich statystycznego opracowania sformułowano następujące wnioski.

1. Zjawisko rozciągania próbek stali EPSTAL należy opisać jednowymiarowym niestacjonarnym procesem stochastycznym $\sigma(\varepsilon, \mathrm{e})$.

2. Wielkości mechaniczne prętów stalowych, tj.: granica plastyczności, wytrzymałość na rozciąganie i wydłużenie pod największym obciążeniem są jednowymiarowymi zmiennymi losowymi, dla których zbudowano histogramy tych wielkości dla poszczególnych produkowanych średnic i produkcji prętów w latach 2016 i 2017 . Obliczono także estymatory parametrów liczbowych tych wielkości.

3. Współczynniki zmienności granicy plastyczności prętów o średnicy od 10 do $32 \mathrm{~mm}$ produkowanych w latach 2016 i 2017 przyjęły wartości w następujących przedziałach: 2,09-2,61\% w 2016 roku i 1,79 - 2,87\% w 
2017 roku. Są to wartości małe, tzn. rozrzut granicy plastyczności jest mały. Produkowana stal jest bardzo dobrej jakości.

4. Współczynniki zmienności wytrzymałości na rozciąganie prętów o średnicy od 10 do $32 \mathrm{~mm}$ produkowanych w latach 2016 i 2017 przyjęły wartości w następujących przedziałach: 1,60 - 2,24\% w 2016 roku i 1,43 $2,28 \%$ w 2017 roku.

5. Doświadczalne wartości charakterystyczne granicy plastyczności, tj. wartości $R e,{ }_{5 \%}$ są zawarte w przedziałach 520 - 536 MPa w 2016 roku i 514 - 534 MPa w 2017 roku. Dotychczasowa wartość charakterystyczna przyjęta przez producenta na poziomie $500 \mathrm{MPa}$ jest zaniżona, dla prętów o średnicy $10 \mathrm{~mm}$ około $3 \%$, zaś dla prętów od średnicy $16 \mathrm{~mm}$ od 5 do nawet $6 \%$.

Received 04.04.2019

Revised 11.09.2019 